\title{
The Philosopher's Poet: Twenty-First-Century Perspectives on Wallace Stevens
}

\section{Bart Eeckhout}

\section{(2) OpenEdition \\ Journals}

Electronic version

URL: https://journals.openedition.org/transatlantica/15268

DOI: 10.4000/transatlantica. 15268

ISSN: $1765-2766$

\section{Publisher}

Association française d'Etudes Américaines (AFEA)

Electronic reference

Bart Eeckhout, "The Philosopher's Poet: Twenty-First-Century Perspectives on Wallace Stevens", Transatlantica [Online], 1 | 2020, Online since 01 December 2020, connection on 01 February 2023. URL: http://journals.openedition.org/transatlantica/15268 ; DOI: https://doi.org/10.4000/ transatlantica.15268

This text was automatically generated on 1 February 2023.

\section{(c)}

Creative Commons - Attribution-NonCommercial-NoDerivatives 4.0 International - CC BY-NC-ND 4.0 https://creativecommons.org/licenses/by-nc-nd/4.0/ 


\title{
The Philosopher's Poet: Twenty- First-Century Perspectives on Wallace Stevens
}

\author{
Bart Eeckhout
}

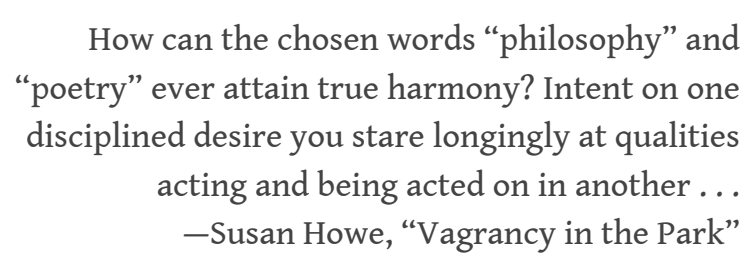

1 A novice reader who develops an interest in the critical framing of Wallace Stevens's poetry by a representative sample of scholarly experts is likely to turn today to at least one of two critical sources, The Cambridge Companion to Wallace Stevens and/or Wallace Stevens in Context. Among the more striking features of these two volumes is the critical place they afford to questions of philosophy: the former contains a synthetic chapter on "Stevens and Philosophy" (Eeckhout, 2007), while the latter divides the attention between chapters on "American Philosophy" (Malkin, 2017) and "European Philosophy" (Ziarek, 2017). For a special issue such as this, it may thus be worth investigating a number of responses that the philosophical qualities of Stevens's work have continued to elicit in recent years.

2 What follows is a critical presentation of a handful of twenty-first-century published responses to Stevens's poetry in relation to philosophy. To ensure that this effort remains sufficiently distinct from the aforementioned chapters (the first of which I have authored myself), the essay will play off two types of response against each other: by five fellow poets, on the one hand, and by two philosophers, on the other. These two opposed angles seem interesting to me precisely insofar as they fall outside mainstream writings on the poet as produced by literary critics. ${ }^{1}$ I want to focus on them here as a literary-sociological exercise and a form of applied reader response theory. This means that the following article is not primarily concerned with reading Stevens's poetry, producing new insight into its philosophical allure, or proposing a 
personal theory about the relation between poetry and philosophy. It also means that several famous voices have been consciously left out of the discussion. On the poetic side, this is the case with a number of major contemporary poets such as Susan Howe and Cole Swensen. While Howe and Swensen have composed some of their most inspired poetry and prose in response to Stevens's work, these writings have addressed the poet's relation to philosophy only indirectly and fleetingly at best. ${ }^{2}$ On the philosophical side, I have excluded the cases of Stanley Cavell and Simon Critchley, both of whom are commonly cited and discussed in Stevens criticism. Instead, I will turn to the only two other philosophers I am aware of as potential twenty-first-century case studies. The essays by Alain Badiou and Peter Hare presented below have not received any attention among Stevens scholars.

3 Thus, the current article introduces a range of voices that are almost entirely unfamiliar to Stevens critics, and are themselves, in turn, barely influenced by such criticism. The categorical distinction among poets, philosophers, and critics on which I fall back here is hardly waterproof, of course, yet it will turn out to have at least some heuristic value. What happens when these five fellow poets, on the one hand, and two philosophers, on the other, weigh in on Stevens's work without laying claim to any academic expertise on the poet? How do they negotiate the difficulties of bringing together poetry and philosophy?

\section{Five Poets Reflecting on the Philosophical Nature of Stevens's Writings}

4 For a minimally diverse sample of contemporary American poets' responses to Stevens's philosophical appeal, we may conveniently turn to David Baker, Linda Gregerson, Carl Phillips, Stanley Plumly, and Carol Frost. Together these poets filled a section in the New England Review in 2016 under the title "The Mind at the End of the Palm: Wallace Stevens Thinking." ${ }^{3}$ Not unusually for American poets, the five writers all teach at a college or university, and are thus presented as belonging to the professional hybrid of "poet-critics." ${ }^{4}$ Yet they are not established Stevens critics; they belong to the many fellow poets who gravitate toward Stevens's work without being academic experts on it. What these writers predominantly publish are books of poetry and non-scholarly essays rather than academic criticism. One of them is also a poetry editor (Baker), another directs a writers' program (Gregerson). The NER, in addition, calls itself a literary magazine, not a scholarly journal, and four of the essays came out of a panel organized during the annual conference of the Association of Writers and Writers Programs. The poets' five brief essays, finally, are personal reflections that come without notes or bibliographies. How does such a sample of contemporary American poets come to terms with the question of Stevens's philosophical importance?

5 Although there is no immediate need to stick to the essays' sequence of publication, David Baker's opening contribution is worth looking at first and in most detail, not only because it is meant to introduce the cluster of reflections but also because of how it does so. Baker starts by asserting what is largely an established opinion-that "Wallace Stevens is one of our supreme knowers, one of the profound thinkers of, and inside, the lyric poem." Yet he quickly admits to being at a loss about how to deal with Stevens's formidable reputation as a "philosophical poet" (2016 24). He is happy to praise the 
poet's collection of aphorisms for their "great baffling clarities, those one- and twosentence zingers of which Americans are so fond," but struggles with the fact that in those aphorisms, and in the poetry, "Stevens says almost everything," so much so that "his work can be made to fit [and] to prove [...] almost every [philosophical] stance" imaginable. This leads Baker to propose that "Stevens is one of the great lyric chameleons" in American poetry, but also to wonder to himself, "Is he a philosopher?" (2016 25)

6 That is obviously a tricky question for a poet to answer, not only because it sounds so essentialist but also because poets may feel institutionally ill-placed to decide on who counts as a philosopher. Having asked the question, nevertheless, Baker comes up with a remarkable solution: he suspends his own judgement and surrenders to the territorial logic of academic disciplines. Instead of proposing a tentative personal answer, he starts by putting the question to "three poetry friends, who by profession are philosophers." The first of these, Troy Jollimore, happens to be an analytic philosopher. In my chapter on "Stevens and Philosophy" published over ten years ago, I already speculated on the fundamental mismatch there seems to be between Stevens's interests, or ways of thinking, and those that have become hegemonic in AngloAmerican philosophy departments today, with their widespread focus on analytic philosophy (Eeckhout, 2007 106; see also Han, 2019 162-69). These speculations are now anecdotally confirmed by Baker's experiment: at his request, Jollimore tries to give some deep thought to the question of Stevens's status as a philosopher, and then concludes she has very little to say on the matter (2016 25).

7 The second philosopher contacted by Baker proves less willing to comply with the synthetic claims I put forward in my contribution to The Cambridge Companion to Wallace Stevens. At the time, I proposed that Stevens's poetry accommodates philosophical appropriations in the Continental European tradition much more readily than in the Anglo-American analytic one. Yet despite her own training in Continental philosophy, Kascha Semonovich resists a critical approximation: she personally does not "think philosophy and poetry are terribly similar," and sees especially a "significant" difference "between sustained analysis and mere "philosophical moments." Semonovich deplores, in particular, the lack of a "system" of justification in Stevens's poetry, and "without justification you just have beliefs" (2016 25). Her objection thus exemplifies one of the most recurrent obstacles to a productive rapprochement between poetry and philosophy: the philosopher's common demand for systematic reasoning. Stevens, we might remind ourselves, was fully capable of systematic reasoning because it informed his daytime job as one of the country's most respected lawyers in the insurance business. But he was also adamant about the need for poetry to avoid all forms of intellectual containment, let alone any systematic search for insight. In one of his published letters, he notes, "I have never studied systematic philosophy and should be bored to death at the mere thought of doing so" (Stevens, 1996 636). In another, he explains that "It is difficult for a man whose whole life is thought to continue as a poet. The reason (like the law, which is only a form of the reason) is a jealous mistress" (Stevens, 1996 761). And in one of his aphorisms, he provocatively proposes, "Perhaps it is of more value to infuriate philosophers than to go along with them" (Stevens, 1997 906).

8 Baker's genial attempt at restoring the dialogue between philosophers and poets thus seems destined to revive some of the ancient antagonisms and mutual 
misunderstandings between the two kinds of writer, and to be leading only to further territorial retrenchment. Fortunately for his experiment, however, there is still John Koethe as his third sparring partner. Koethe proves to be a much more welcoming interlocutor: not only is he both an established poet and an established philosopher, he once even contributed a brief reflection to The Wallace Stevens Journal. Against his two distancing colleagues, Koethe seeks to cast a bridge between poetry and philosophy by following one of Stevens's own ideas-that we should distinguish "between systematic thinking and 'the movements of consciousness." We might take an interest in Stevens's poetry, Koethe proposes, to the extent that we are able to share the poet's "dissatisfaction in the very system of intellectual construction that defines both philosophy and the logical or reasonable rhetoric of legal argument out of which Stevens's very day-job derives" (2016 25; Baker's paraphrase). To Koethe, Stevens's value as a poetic thinker lies exactly in his resistance to system-building and his agile ways of tracing the movements of consciousness. This argument is very similar, we will see, to the pragmatist argument by Peter Hare.

9 From his conversation with philosophers Baker concludes that poetry almost never "does" philosophy, and that we should ask different questions of it instead. For the remainder of his essay, he then proposes to look at "three kinds of rhetorical paradigms in Stevens's poetry, none of them ultimately 'doing' philosophy.” (2016 26) He chooses to return, in other words, to poetically familiar terrain, which we might call that of rhetorical modes. He starts by considering those "crystalline" poems by Stevens that love to "suggest-and to parody-a kind of methodology" which is really a "pastiche of [the] process" of reasoning (2016 26). Such mimicry of reasoning, he argues, only seems like philosophy; in reality, it acts as "a tautology of the indecipherable." (2016 27) Second, in the work after Harmonium (1923) Stevens builds out to the "more rhetorically sustained [...] speculative poem" that perhaps comes "closest to philosophy." Yet in Baker's opinion, the "finest poems" are those in which Stevens "is most truly a meditative poet." (2016 27) Agreeing with Roger Gilbert's classic study of the "walking poem" in modern American literature, Baker describes these poems as instances where "to meditate is to amble" (2016 27). He takes "An Ordinary Evening in New Haven" as an example, describing it by saying, "It's as much music as method, and more amusement than analysis." This allows Baker to reach his personal conclusion: to him, Stevens "feel[s] by thinking" in his poetry. "Thinking makes him nearly ecstatic" (2016 28).

There is no need to cover the other poets' essays in similar detail. What matters to this bird's-eye view, after all, are recurrent patterns. And the first general observation to be made is that all five poets conspicuously evade the question of philosophy as philosophy. Without exception, what they prefer to look at are Stevens's idiomatic ways of lyric thinking, unconnected to any names or theories from the history of philosophy. Apparently sharing Baker's initiating skepticism about whether Stevens might be regarded as a philosopher in his own right, they are satisfied to reflect on Stevens's poems as sensitive close readers. The most probing essay in this regard is, arguably, Carl Phillips's “Thinking Versus Imagination." Phillips's contribution takes off from the opening aphorism of Stevens's poem "Crude Foyer": "Thought is false happiness" (Stevens, 1997 270). After a few preliminary hypotheses about how Stevens likely identifies the notion of "thought" in this instance with a tendency toward literal rather than figurative thinking, as well as with a search for the satisfactions of intellectual closure, Phillips modestly notes that he does not really have "any firm 
theories about Stevens' poems." Instead, he prefers to embark on an analysis of what might be called the formal enactment of modes of thinking in Stevens. He reminds us, on the basis of concrete passages, how Stevens's "expansion of sentence length," with its "accompanying increase in syntactic complexity and [...] intensification of repetition," works as a way "to enact [...] a restlessness of mind" (2016 34). He further interprets examples of ellipsis and stanza break, the ghostly presence of a volta in many of the poems, Stevens's use of anaphora and chiasmus, of enjambment and caesura (2016 35-37). A subtle discussion of these poetic features persuasively demonstrates how poetic form can be used to dramatize thinking, and how exactly Stevens uses such tools to distill lyric verse out of his meditating mind. But it also implicitly refuses to take the measure of Stevens's larger philosophical import and place, which evaporate as possible questions to ask of his work.

11 The same approach, centered on a detailed consideration of the formal features of specific poems, recurs throughout, and it ultimately renders these five poets' pursuits more Vendlerian-i.e., composed in the spirit of Helen Vendler's aesthetically oriented criticism on Stevens-than philosophical. Linda Gregerson's investigation of "The 'Predicate of Substance"' still has most philosophical heft in tracing what she calls, alternatively, "an irreducible oxymoron" or "an aporia" in Stevens's work (2016 31). But it, too, in the end, is about her coming to terms with a handful of passages from "The Auroras of Autumn." The textual connections she establishes in passing are with John Milton and George Puttenham (2016 30, 31), not with any theoretical or philosophical thinkers. For Stanley Plumly as well, the intertextual focus is on other poets thinking-predominantly John Keats and T.S. Eliot-not on any philosophical intertexts. Most characteristically, perhaps, Carol Frost zooms in on Stevens's use of the poetic imperative, and demonstrates-quite convincingly for those who take an interest in the matter-that there is an as yet unidentified poetic subtext to "The Emperor of Ice-Cream": the Jacobean playwright John Webster's dirge (included in his play The White Devil) "Call for the Robin-Redbreast" (2016 44-46).

There is no doubt, then, that these personal reflections and readings of Stevens's work are sensitive, subtle, and composed in a collaborative spirit that seeks to draw out affinities between philosophical thinking and lyric writing. But it is equally clear how circumspect and oblique they tend to be, how little inclined to address the question of Stevens's philosophical qualities head on. Their implied audience seems to be that of other poets, not of philosophers or of literary theorists wishing to establish a productive encounter between the two kinds of writing. From a sociological perspective, then, what is most striking about these responses to the question of Stevens's philosophical importance is how much the five poets appear to be intimidated by it-whether this is due to the formidable reputation of Stevens's poetry, their own experiences with it as readers, the status of philosophy as an academic discipline, the jargon and scope of literary theory, or any combination of such factors.

\section{Philosophers' Reflections: The Case of Alain Badiou}

13 As we saw in the introduction, an exhaustive overview of twenty-first-century philosophers responding to Stevens's work would have to include figures such as Stanley Cavell and Simon Critchley. But both of these thinkers have already received considerable attention in Stevens criticism, unlike the two philosophers presented 
here, Alain Badiou and Peter Hare. Narratively, it makes most sense to organize this part of my survey from East to West, starting in France and moving back to the U.S. In rudimentary terms, this entails a movement from the post-Marxist and post-1968 French thinking of Badiou to the tradition of American pragmatism reaching back to Charles Sanders Peirce and William James. Let us note, as a further preamble, that the two philosophers' references to Stevens are explicitly testimonies of affinity and affiliation. Indeed, no philosopher would feel the urge to engage with Stevens's challenging Modernist verse out of sheer animosity: the poet's symbolic capital and sociopolitical importance outside the niche of poetry readers is too limited for that.

Sometime in the early 2000s (the published offshoot mentions no precise date), Badiou gave a talk under the title "Le dessin." It remained unpublished as such in French, but appeared in English translation in 2006 as "Drawing: On Wallace Stevens," and has since been included in a collection of Badiou's essays published by Verso in 2014, The Age of the Poets and Other Writings on Twentieth-Century Poetry and Prose. Although there is a colon between the main title of the translation and its subtitle, the striking ambiguity in English invites us also to omit the colon and wonder how Badiou draws on Stevens in this essay. As soon as we do so, the shift from the poets considered in the previous section is immediately apparent: for his part, Badiou does not appear to be interested in analyzing the formal and aesthetic strategies of Stevens's poetry. Rather, he mines the American's writings, inspirationally but to some extent also just instrumentally, to help him address a larger philosophical question that preoccupies him. The aim of his article, as he defines it at the outset, is to "propose a very general definition of the arts, more precisely of contemporary arts," and then to offer "a short definition of drawing." Understandably, this makes him turn to Stevens's poem "Description Without Place," which has long acted as a magnet on theoretically minded readers-we will see it coming back later. To start off his reflection, Badiou borrows the arresting title of Stevens's poem to define what to him "every work of art, especially every work in contemporary arts," amounts to-descriptions without place-although he does not tell the reader in advance that it will be necessary to activate different meanings of "without place" at different points in his text. In the case of an art installation, for instance, Badiou seems to be interested primarily in the subversive re-placement of things so that they wind up "outside their normal place," whereas in the case of a performance his interest appears to be more in possibilities for ecstatic description through which we enter "a space that is strictly speaking outside itself" (2014 75).

To define the art of drawing, Badiou inflects Stevens's phrase still differently. "A drawing," he argues, "is a complex of marks," and "These marks have no place" (2014 75). This is the case because the marks, as soon as they are inscribed, "create the background as an open space. They create what Mallarmé names 'the blank paper guarded by its white"' (2014 76). The reference to Mallarmé is no coincidence: the father of French Symbolism has long been a major source of inspiration for Badiou's thinking about literature, and he recurs plentifully throughout The Age of the Poets. In general, Mallarmé's inspirational value seems to be the result of Badiou's longtime interest in the autonomy of the artwork. Yet it may also say something about how Badiou situates Stevens for himself-as a writer who stands in this Symbolist tradition and does not belong, for instance, with the poets discussed elsewhere in the volume under "Poetry and Communism." 

"Fortunately," he observes, "one point in the poem of Wallace Stevens surprises me" (2014 76). That phrase-“one point in the poem"-might be expected to refer to an actual passage in the text for any of the five poets just mentioned, but for Badiou the point is an idea, not a textual crux. He cites Stevens's opening lines from "Description Without Place": "It is possible that to seem-it is to be, / As the sun is something seeming and it is" (Stevens, 1997 296). This notion of the "inseparability of being and appearing" is used to define what is "exactly the problem of drawing" (Badiou, 2014 76, 77). Instead of teasing out the complexities of Stevens's poem, however, Badiou's philosophical attention instantly veers toward the familiar dialectic between presence and absence, steered in this case toward "the fundamental fragility of drawing" and a kind of Deleuzian "disjunctive synthesis" enacted and embodied by the art of drawing (2014 77).

The extent to which we might gain insight into "Description Without Place" as a poem remains uncertain when Badiou returns to it and calls Stevens "a critic of two historical definitions of beauty and art" (2014 77). He notices that Stevens at one point in the text offers the following epigram: "Description is / Composed of a sight indifferent to the eye" (Stevens, 1997 300). Badiou connects this to the Platonic idea that "real beauty is always beyond appearances," and then dismisses the entire lineage by saying, "Stevens does not agree, and I do not agree either" (2014 77). In a similar gesture, he detects traces of the Romantic idea that "beauty is the sensitive form of the Idea" (2014 78) in Stevens's claim, elsewhere in the poem, that "description is revelation" (Stevens, 1997 301). But he is equally dismissive of that manner of thinking: the poem itself supposedly shows that "this is not the case" (2014 78), because the work of art, in Stevens's words, "is not / The thing described" (Stevens, 1997 301). To an experienced reader of Stevens criticism, such proclamations may come across as rather unhelpful, for two reasons. First, Badiou limits himself to cherry-picking brief, philosophically sounding aphorisms that are largely of a declarative, abstract, and nonfigurative sort, without looking at how this language interacts with the surrounding imagery, formal features, and linguistic inventions of the poem. And second, he extracts these statements from their immediate context, treating them as if they contributed toward a single philosophical argument in the text, rather than as participating in those ambulatory, open-ended movements of consciousness pointed out by Baker and Koethe. It is worth keeping this objection in mind, because we will see how Peter Hare makes it crucial to his own philosophical approach.

Badiou, meanwhile, engages in further system-building, returning to Stevens one more time to illustrate his own basic "theory of a work of art as a point where appearing and being are indiscernible." For this illustration, he turns to "The Man with the Blue Guitar." Badiou appreciates Stevens's variations on the image of a blue guitar especially because they offer, within "the artificial world created in language by Stevens [...] a poetical intensity in which being and existence are identical" (2014 80). This he then "transfer[s] [...] to the experience of drawing," which likewise constitutes "a new way of existing for the true being of the thing." Yet if such discourse on the "true being" of artistically created things may be ontologically more essentialist than Stevens's poetics tends to support, readers are still in for a last surprise: on his final page, Badiou pivots to address a topic that has been absent altogether from his definitional exercise, or from his use of Stevens. The primacy of the political seems to assert itself when Badiou 
raises the "relationship between drawing and politics," and proclaims that traditional "revolutionary politics [...] is a description with places," whereas the time has come to "create a new trend of politics"-a "purely displaced politics, with absolute equality as its fundamental concept" (2014 81). This language of purities and absolutes is notably un-Stevensian again, and Badiou's elliptical invocation of a new politics is not much clarified by his subsequent call for an "international and nomadic creation with-as in a work of art-a mixture of violence, abstraction and final peace" (2014 81-82). It is hard to fathom where in the previous pages this utopian drive for final peace comes from, although Badiou is able to anchor it once more in a few decontextualized lines from Stevens-this time from the ending of "Final Soliloquy of the Interior Paramour," in which the poet proposes to "make a dwelling in the evening air[,] / In which being [there] together is enough" (2014 82; Stevens, 1997 444). ${ }^{5}$ Badiou ends his essay with what sounds like his previously unspoken agenda: "we may perhaps speak of a politics of drawing" (2014 82). But whether or not one supports this politicization of the art of drawing, readers interested in a better understanding of the philosophical qualities of Stevens's poetry are largely left to wonder how they are served by Badiou's meditation and his apparent insistence on the primacy of the political. Despite the essay's subtitle, "On Wallace Stevens," it has not become clear what it is that Badiou as a philosopher wants to say on the topic of Stevens as an inspiring poet. All he appears to have been doing is to extract a few lines from the poet's work, giving them a very specific spin to serve Badiou's own theoretical purposes.

\section{Philosophers' Reflections: The Case of Peter Hare}

That philosophical approaches toward Stevens may differ widely becomes obvious when we finally switch from Badiou to Hare. The name of Peter Hare may be less familiar to a European readership. As an unassuming man (in the description of those who knew him) he did not publish much. By contrast, he believed strongly in his role as a facilitator-for instance, as longtime editor of the Transactions of the Charles S. Peirce Society, a journal with an explicitly pluralistic stance toward American philosophical traditions. For most of his career, Hare, who in his later years was married to Susan Howe, taught in the philosophy department at Buffalo in upstate New York. As his credentials indicate, he stands in the pragmatist tradition of Peirce and William James. He died in 2008 and, seven years later, a selection of his writings was published under the title Pragmatism with Purpose. The collection contains a section on poetry with three essays in which Stevens figures, twice in a more subservient role, once as a central topic.

The best way to present these materials here is again to follow the sequence in which the essays are reprinted, starting with Hare's reflection on "What Are Poets For? Contextualism and Pragmatism." The contrast with Badiou is instantly clear: whereas the French thinker uses Stevens's poetry to propose a general definition of the arts and, particularly, drawing, Hare tends to reject universalizing declarations about artistic instrumentality. He contends that "any context-neutral account of the nature and function of poetry is doomed either to be defeated by counter examples or to becoming banal. And this banality cannot be avoided by a Wittgensteinian move in which the competing forms and functions of poetry are said to share family resemblances." To Hare, "a context-neutral attempt to state the function of poetry"-or, in Badiou's case, 
to define the art of drawing by drawing on a handful of decontextualized lines from Stevens's verse-"is as pointless as a context-neutral effort to state the function of human hands" (2015 210). Attempts at general definition run the risk, furthermore, of denying the specific language/media used by various arts. Hare gives the example of a metaphysically oriented book subtitled On the Concept of Poetry. He agrees with a colleague who deplored how all the beautiful theorizing in this book failed to "illuminate the internal dynamics of a poem, how the features sound, rhythm, language, imagery and meaning develop in the poem" (Roland Garrett qtd. in Hare, 2015 210-11). This is an appropriate reminder not only coming after the example of Badiou, who likewise does not acknowledge any of these aspects in Stevens's poetry, but also because the same lack of attention to form, style, and tone characterizes Simon Critchley's generally appreciative study of the poet, Things Merely Are: Philosophy in the Poetry of Wallace Stevens, and, finally, because attention to the very same elements appeared to be the one major concern shared by the five poets covered in the first section.

Hare's second essay on poetry carries as a title "Misunderstandings between Poet and Philosopher: Wallace Stevens and Paul Weiss." Despite the historical nature of its case study, this essay, too, invites application across the corpus of philosophical responses to Stevens, for Hare's story revolves around the poet's late essay "A Collect of Philosophy," which Critchley as a philosopher notably dismisses. Critchley regrets that

Stevens sometimes betrayed a rather impoverished conception of philosophy [...]. This becomes particularly annoying in the 1951 lecture, "A Collect of Philosophy," where we are treated to unadorned extracts from Stevens's correspondence with Paul Weiss, Jean Wahl and Jean Paulhan and half-digested lumps of Rogers's A Student's History of Philosophy and Alexander's Space, Time and Deity [...]. Thin gruel indeed! (2005 49)

True to his own word that we need to contextualize our understanding of the relations between poetry and philosophy, Hare digs into the actual historical context of the mutual misunderstandings between Stevens and the Yale philosopher Paul Weiss, who rejected Stevens's essay for publication in The Review of Metaphysics after having helped the poet write it and originally having praised the results. Because Critchley is probably unfamiliar with this background story, he merely repeats Weiss's misunderstanding as a philosopher. Hare, meanwhile, insists that "Stevens and Weiss failed to understand one another despite each author's deep respect for the other's discipline," and despite Weiss's "maverick" status in midcentury due to his interest in, among other things, metaphysics and poetry (2015 216). There was, as Hare demonstrates, a lot of affinity between Stevens and Weiss, as well as the best of intentions on either side-as there continue to be, obviously, in Badiou's and Critchley's engagements with Stevens's work.

Although there is no room here to reproduce the details of the story that Hare reconstructs, it is worth signaling that Weiss, in an unpublished part of the interview he gave much later to Peter Brazeau for Brazeau's oral biography of the poet, regretted his own failure to grasp the intentions and complexities of Stevens's essay (2015 223). For himself, Hare draws two rather surprising conclusions from his case study. The first is that the "benefits of personal interaction between [a] poet and [a] philosopher are [...] problematic"; he talks of "unhappy [...] interactions" that "seldom" lead to any "agree[ment] on the natures of their disciplines," which in turn is "a serious barrier to cooperation." These are surely somewhat unexpected confessions, coming from a philosopher who was himself married to a major poet. Hare's second conclusion is 
equally unexpected: he feels that encounters such as the one between Stevens and Weiss, in spite of the many misunderstandings between the two men, demonstrate that these encounters "can be stimulating and productive," even if he fails to spell out how and why (2015 224). He concludes his case by returning one more time to Weiss's retrospective assessment of Stevens's value as a phenomenological thinker-an assessment that happens to be very much in line with Critchley's argument in Things Merely Are. To make his point, Weiss turned to the same opening lines from "Description Without Place" whose appeal on Badiou we already witnessed: "It is possible that to seem-it is to be, / As the sun is something seeming and it is" (Stevens, 1997 296). Indeed, in Hare's comments following this citation, the name of Weiss might well be replaced by that of Badiou. As Hare notes, "Weiss found that these lines expressed something 'very close' to what he was thinking. But he immediately addsnote the cherry-picking-that there are other parts of the poem 'which seem to indicate something quite different from what I intend [...]. And this I would say is an error"' (2015 225). Here we encounter the same cherry-picking at work in Badiou's reflections on Stevens's poem, and then the same dismissal of seemingly contradictory statements elsewhere in the text, apparently because internal contradictions by definition need to be resolved through reasoning.

This recurrent manner of dealing with Stevens's poetry by philosophers such as Weiss and Badiou is one that Hare goes on to criticize in his third and final Stevensmentioning essay, "Deep Conceptual Play in William James." There he returns briefly to the misunderstandings between Stevens and Weiss to comment upon them in a manner that arguably has wider relevance to philosophical appropriations of the poet. Hare claims that "Weiss mistakenly assumes that a poet qua poet should-at least within a single poem-espouse an epistemology that is both sound and self-consistent." (2015 232) Against this, Hare proposes the more complex notion that

Stevens regarded each of the competing epistemologies as metaphorical structures. It is difficult perhaps for those of us whose daily bread is earned by grappling earnestly with epistemological arguments to "get our minds around" the notion of an epistemological theory as a metaphor, but I submit that this is not a difficult notion for a poet with strong philosophical, especially epistemological interests, as Wallace Stevens was. (2015 232)

If we pursue this line of thinking, there is "no reason to suppose that the poet is committed to the truth of one of the epistemologies. After all, no one doubts that it is appropriate to have more than one metaphor in a single poem" (2015 232). This is where Hare moves closer again to Critchley's appreciation of Stevens: he celebrates that "what a poet does with concepts, using them as metaphors, can loosen the grip that a concept has on the reader, including the philosophical reader" (2015 233). Hare then turns to William James's advocacy of "the power of playing with thought and language" (qtd. in Hare, 2015 235)-what he further develops as the activity of "deep play," which he connects, via Friedrich Schiller's Spieltrieb, to Peirce's notion of "musement" (2015 236, 240). Such deep play he sees as lying "at the intersection of the artistic, the philosophical, the religious, the mathematical, and the scientific" (2015 241).

of the seven responses to Stevens's philosophical importance presented in my overview, Hare's thus appears to be the most productive one. It offers us a number of practical handles, helpful notions, and a fitting larger framework. It reminds us, in particular, of several valuable principles: that we need to contextualize the question of poetry's relation to philosophy (and vice versa) if we want the answers to cut deep; that 
we may certainly appreciate Stevens as a phenomenological thinker provided we value also the consciously contradictory nature of his lyric proclamations and do not reduce his ideas to cherry-picked one-liners; that all along we need to understand the "deep play" with thought and language in which Stevens's verse engages; and that this implies an understanding of how epistemologies may serve a metaphoric rather than a conceptual function. To be sure, Hare does not try his hand at reading any particular Stevens poem and what he offers is still limited to a set of principles and analytical tools. In the end, it remains for the literary critic to set these principles and tools to work in particular readings.

\section{Conclusion}

The final example of Hare's writings serves as an excellent reminder of the need to be wary of decontextualized extrapolations from the concrete to the general, especially when we are dealing with the conjunction of poetry and philosophy, two types of writing that tend to set the concrete and general to such different uses. By pitting the voices of poets against those of philosophers, the preceding survey has sought to dramatize some of the difficulties typically confronted by poets and philosophers when they seek to find common ground between their respective genres. My case study has allowed the reader to observe directly, on empirical grounds, how poets often remain wary of addressing Stevens's philosophical weight except by noting how the poet's mental activity is formally and stylistically enacted in his verse, while several philosophers who are attracted to Stevens's writings (from Weiss to Badiou and Critchley) fail to acknowledge the intrinsic nature of lyric thinking, and thus do not always manage to contribute to a deeper understanding of the poetry as such. If Hare builds an exception, he does so in a notably diffident and unassuming manner, taking his time to gather contextual evidence and merely preparing the ground for the philosophically minded reader to encounter Stevens's poetry again in all of its wish to "resist the intelligence almost successfully" (Stevens, 1997 910).

\section{BIBLIOGRAPHY}

ALTIERI, Charles. Wallace Stevens and the Demands of Modernity: Toward a Phenomenology of Value. Ithaca: Cornell University Press, 2013.

BADIOU, Alain. "Drawing: On Wallace Stevens." The Age of the Poets. Ed. Bruno Bosteels. Translated from the French by Bruno Bosteels. London: Verso, 2014, p. 75-82.

BAKER, David. "Feeling Thinking." New England Review, vol. 37, no. 1, 2016, p. 24-28.

BARTCZAK, Kacper, and Jakub MÁCHA, editors. Wallace Stevens: Poetry, Philosophy, and Figurative Language. Berlin: Peter Lang, 2018. 
CAVELL, Stanley. "Reflections on Wallace Stevens at Mount Holyoke." Artists, Intellectuals, and World War II: The Pontigny Encounters at Mount Holyoke College, 1942-1944. Eds. Christopher E.G. Benfey, and Karen Remmler. Amherst: University of Massachusetts Press, 2006, p. 61-79.

CRITCHLEY, Simon. Things Merely Are: Philosophy in the Poetry of Wallace Stevens. London: Routledge, 2005.

EECKHOUT, Bart. "Stevens and Philosophy." The Cambridge Companion to Wallace Stevens. Ed. John N. Serio. Cambridge: Cambridge University Press, 2007, p. 103-17.

EYERS, Tom. "Alain Badiou, Wallace Stevens and the Paradoxical Productivity of Poetic Form." Textual Practice, vol. 30, no. 5, 2016, p. 835-55.

FROST, Carol. “The Poetic Imperative.” New England Review, vol. 37, no. 1, 2016, p. 43-46.

GILBERT, Roger. Walks in the World: Representation and Experience in Modern American Poetry. Princeton: Princeton University Press, 1991.

GOLDFARB, Lisa. The Figure Concealed: Wallace Stevens, Music, and Valéryan Echoes. Brighton: Sussex Academic Press, 2011.

GOLDSTONE, Andrew. Fictions of Autonomy: Modernism from Wilde to de Man. Oxford: Oxford University Press, 2013.

GREGERSON, Linda. “The 'Predicate of Substance.” New England Review, vol. 37, no. 1, 2016, p. 29-32.

HAN, Gül Bilge. Wallace Stevens and the Poetics of Modernist Autonomy. Cambridge: Cambridge University Press, 2019.

HARE, Peter. Pragmatism with Purpose: Selected Writings. Eds. Joseph Palencik, Douglas R. Anderson, and Steven A. Miller. New York: Fordham University Press, 2015.

HOWE, Susan. The Quarry. New York: New Directions, 2015.

HOWE, Susan. Souls of the Labadie Tract. New York: New Directions, 2007.

KOETHE, John L. "Helen Vendler's Stevens: A Poet of Language-Driven Meditations." The Wallace Stevens Journal, vol. 38, no. 2, 2014, p. 151-52.

KOSTOVA, Raina. "Deleuzian Underpinnings: The Affective Emergence of Stevens' Concept of a Supreme Fiction." The Wallace Stevens Journal, vol. 35, no. 1, 2011, p. 33-55.

KOTIN, Joshua. “Wallace Stevens's Point of View.” PMLA, vol. 130, no. 1, 2015, p. 54-68.

LEHMAN, Robert S. "Abstract Pleasures: Romanticism and Finitism in the Poetry of Wallace Stevens.” Modern Philology, vol. 111, no. 2, 2013, p. 308-28.

MALKIN, Rachel. “American Philosophy." Wallace Stevens in Context. Ed. Glen MacLeod. Cambridge: Cambridge University Press, 2017, p. 217-26.

MILLER, J. Hillis. "Western Theories of Poetry: Reading Wallace Stevens's 'The Motive for Metaphor." Thinking Literature across Continents. Eds. Ranjan Ghosh and J. Hillis Miller. Durham: Duke University Press, 2016, p. 93-110.

PHILLIPS, Carl. "Thinking Versus Imagination.” New England Review, vol. 37, no. 1, 2016, p. 33-38. PLUMLY, Stanley. “Does Ripe Fruit Never Fall?” New England Review, vol. 37, no. 1, 2016, p. 39-42. POPOVA, Yanna B. “The Real and the Ordinary in Stevens' Poetry: Enaction, Embodied Consciousness, and Phenomenal Experience in 'The Emperor of Ice-Cream'." The Wallace Stevens Journal, vol. 40, no. 2, 2016, p. 185-98. 
RAGG, Edward. Wallace Stevens and the Aesthetics of Abstraction. Cambridge: Cambridge University Press, 2010.

RICHARDSON, Joan. How to Live, What to Do: Thirteen Ways of Looking at Wallace Stevens. Iowa City: University of Iowa Press, 2018.

STEVENS, Wallace. Letters of Wallace Stevens. Ed. Holly Stevens. Berkeley: University of California Press, 1996.

STEVENS, Wallace. Wallace Stevens: Collected Poetry and Prose. Eds. Frank Kermode and Joan Richardson. New York: Library of America, 1997.

SWENSEN, Cole. "Perhaps the Truth Depends." The Wallace Stevens Journal, vol. 43, no. 2, 2019, p. 250-63.

TOMPSETT, Daniel. Wallace Stevens and Pre-Socratic Philosophy: Metaphysics and the Play of Violence. London: Routledge, 2012.

WOLFE, Cary. Ecological Poetics; or, Wallace Stevens's Birds. Chicago: University of Chicago Press, 2020.

ZIAREK, Krzysztof. “European Philosophy.” Wallace Stevens in Context. Ed. Glen MacLeod. Cambridge: Cambridge University Press, 2017, p. 227-35.

\section{NOTES}

1. Apart from the three chapters by Eeckhout, Malkin, and Ziarek, readers with an interest in recent philosophically and theoretically inspired responses to Stevens's work are advised to turn to Altieri, 2013; Bartczak and Mácha, 2018; Critchley, 2005; Eyers, 2016; Goldfarb, 2011; Goldstone, 2013; Han, 2019; Kostova, 2011; Kotin, 2015; Lehman, 2013; Miller, 2016; Popova, 2016; Ragg, 2010; Richardson, 2018; Tompsett, 2012; and Wolfe, 2020.

2. Howe has composed both a series of poems in response to Stevens, "118 Westerly Terrace" (included in Souls of the Labadie Tract), and a long two-part essay, "Vagrancy in the Park," that leads off her collection of essays The Quarry (see, respectively, Howe, 2007 and Howe, 2015). Swensen is the author of an extended meditation on Stevens in a hybrid genre that consists of prose transforming occasionally into poetry (see Swensen, 2019).

3. The title plays on "The palm at the end of the mind," the opening line of Stevens's supposedly last poem, "Of Mere Being" (Stevens, 1997 476). Its playful reversal, we might immediately note, is more typical of poets' than of philosophers' responses to Stevens.

4. This is the designation used in the brief, unattributed editorial preface that sits on top of Baker's opening essay (2016 24).

5. The punctuation and word in square brackets are in Stevens's poem but missing from Badiou's citation. 


\section{ABSTRACTS}

This article investigates how the relation between poetry and philosophy is developed in a sample of reflections on the philosophical qualities of the American Modernist poet Wallace Stevens's work. It offers a critical presentation of a handful of twenty-first-century published responses to Stevens's poetry emanating from two different quarters: fellow poets and philosophers. The five selected poets (David Baker, Linda Gregerson, Carl Phillips, Stanley Plumly, and Carol Frost) collectively pondered Stevens's philosophical qualities in a recent issue of the New England Review, while the responses by philosophers Alain Badiou and Peter Hare were published in collections of their essays. The two different angles are investigated precisely because they fall outside mainstream literary criticism on Stevens and help to dramatize several of the difficulties confronted by poets and philosophers seeking to find common ground. By pitting the voices of poets against those of philosophers, the article allows the reader to observe empirically how poets are often wary of addressing Stevens's philosophical weight except by noting the formal and stylistic enactment of mental activity in his verse, while philosophers sometimes fail to acknowledge the intrinsic nature of lyric thinking, and thus do not always manage to contribute to a deeper understanding of the poetry as such.

Cet article s'interroge sur la manière dont la relation entre poésie et philosophie se développe dans certaines réflexions sur la portée philosophique de l'œuvre du poète moderniste américain Wallace Stevens. Il dresse le portrait critique de certaines réponses proposées au vingt-et-unième siècle à la poésie de Stevens, qui proviennent de champs différents : poésie d'un côté, philosophie de l'autre. Les cinq poètes choisis dans le cadre de cette étude (David Baker, Linda Gregerson, Carl Phillips, Stanley Plumly, et Carol Frost) se sont collectivement penchés sur les ressorts philosophiques de Stevens dans un numéro récent de la New England Review, tandis que les réponses apportées par les philosophes Alain Badiou et Peter Hare ont été publiées dans des ouvrages recueillant certains de leurs essais. Nous choisissons de nous intéresser à ces deux approches précisément dans la mesure où la critique littéraire dominante sur l'œuvre de Stevens tend à les ignorer, mais aussi parce qu'elles permettent de dramatiser plusieurs des difficultés auxquelles font face poètes et philosophes à la recherche d'un terrain d'entente. Or en confrontant la voix de poètes à celle de philosophes, cet article propose au lecteur d'observer de manière empirique comment les poètes tendent à se méfier du poids philosophique de Stevens en concentrant leurs efforts sur la façon dont l'activité mentale vient s'incarner formellement et stylistiquement dans les vers du poète, alors que les philosophes ont de leur côté tendance à ignorer la nature intrinsèquement lyrique de la pensée, ne parvenant pas, ce faisant, à proposer une compréhension fine de la poésie en tant que telle.

\section{INDEX}

Mots-clés: Poésie moderniste américaine, Wallace Stevens, Alain Badiou, Peter Hare, Simon Critchley, poésie et philosophie, théorie de la réception, pragmatisme américain

Keywords: American modernist poetry, Wallace Stevens, Alain Badiou, Peter Hare, Simon Critchley, poetry and philosophy, reader response, American pragmatism 
AUTHOR

BART EECKHOUT

University of Antwerp 